\title{
Dopamine receptor type 1 of Caenorhabditis elegans expressing in mechanosensory neurons
}

\author{
V. V. Stadnyk, A. Regosh, C. Y. Mayor, I. S. Fomenko', \\ T. I. Bondarchuk ${ }^{1}$ O. Y. Sklyarov ${ }^{1}$ \\ Eotvos Lorand University \\ Egyetem ter 1-3, Budapest, Hungary, 1053 \\ ${ }^{1}$ Danylo Halytsky Lviv National Medical University \\ 69, Pekarska Str., Lviv, Ukraine, 79010 \\ biochemistry@meta.ua
}

\begin{abstract}
Until now the results on profiling dopamine receptors in C. elegans have been incomplete and fragmentary. The aim of this study was to in-vestigate the expression profile of dop-1 gene in C. elegans using $3 \mathrm{~kb}$ promoter with 3 '-end locating before ATG of dop-1gene. Methods. The strain of C. elegans with mutant unc-119 gene was used. To check a pat- tern of the dop-1 expression, the promoter of this gene was amplified using PCR. The animals were co-bombarded with plasmid pPD95.77 dop-1::GFP and reporter construct containing unc-119 gene. Results. Using GFP as a reporter protein, we built a whole picture of expres- sion of dopamine receptor type 1 in C. elegans and found that this pro- tein could be detected only in mechanosensory neurons such as PLM, PVQR, PVQL, ALNR, ALNL, DVAR, DVC.
\end{abstract}

Keywords: dopamine receptors, mechanosensory neurons, Caeno- rhabditis elegans, expression.

Introduction. Dopamine is one of the most essential neurotransmitters for many animals - from nematodes to mammals. In humans it participates in the regulation of locomotor activity, thinking, emotional state, etc [1]. The disorder in metabolism of this compound may result in a series of wide-spread human diseases, including schizophrenia, Parkinson disease, and Tourette syn- drome [2].

Plant parasitic nematode C. elegans was used as a model organism for over 20 years [3]. Recently its application has been extended to the simulation of neurodegenerative pathologies and design of medical preparations [4]. Therefore, a detailed investigation of the nervous system, including the metabolism of neuromediators and their receptors in C. elegans, is rather urgent.

There are four known dopamine receptors which (by analogy to human receptors) are divided into two

(C) Institute of Molecular Biology and Genetics, NAS of Ukraine, 2012 families: D1, including receptor type 1 (dop-1), and D2, including types 2-4 receptors (dop-2-4) [2].

Previous research on the expression profile of dopamine receptor type 1 revealed rather ambiguous results as the works demonstrated different patterns of neurons, where a reporter construction was expressed. This can be explained by uneven length and structure of promoters, used in these works [5-7]. Therefore, it was decided to conduct a more detailed analysis of expression profile of dop- 1 in C. elegans, using $3 \mathrm{~kb}$ promoter with 3'-end locating before ATG of the dop-1 gene. The promoter length was selected based on the task of obtaining the most specific expression pattern, independent from other DNA regulating elements, which may be located in longer promoters and cause the expression of the reporter protein in non-target neurons.

Materials and Methods. Strains. The strain $C$. elegans with a mutant unc-119 gene, leading to almost complete paralysis of animals, was used. The strain was obtained from the Genetic Center of Caenorhabditis 
(USA). The cultivation was conducted on Petri dishes with NGM-agar. The nutrient medium was Escherichia coli bacteria of OP50 strain (OP-50).

Genetic constructions. To check the expression pattern of $d o p-1,3 \mathrm{~kb}$ promoter of this gene was amplified using a protocol of single worm polymerase chain reaction (PCR) [8]. Then the promoter of dop-1 gene was built into $p P D 95.77$ (Add-gene, USA) at restriction sites HindIII and Cfr9I to obtain the construction pPD95.77dop-1: GFP (Fig.1).

Gene bombardment of $C$. elegans. Animal cells were co-bombarded with plasmid pPD95.77dop-1: :GFP and reporter construction pRH21Unc119 (Prof. A. Fire's lab, USA) with unc-119 gene, promoting restoration of the wild phenotype. The bombardment was

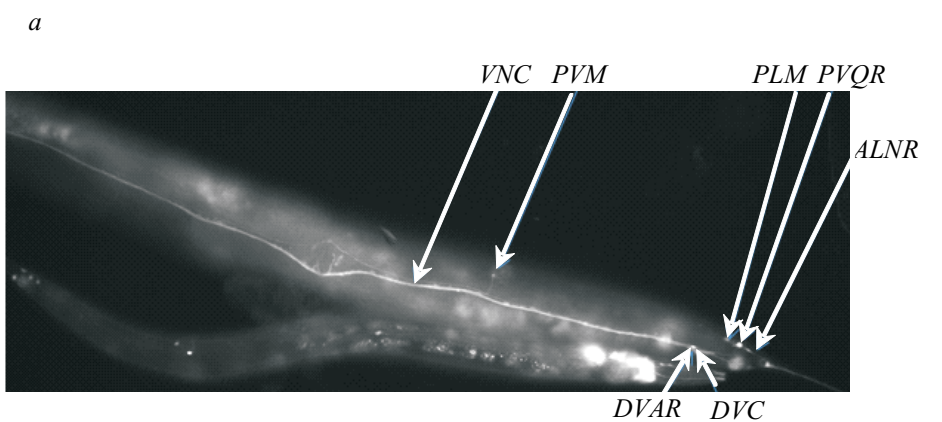

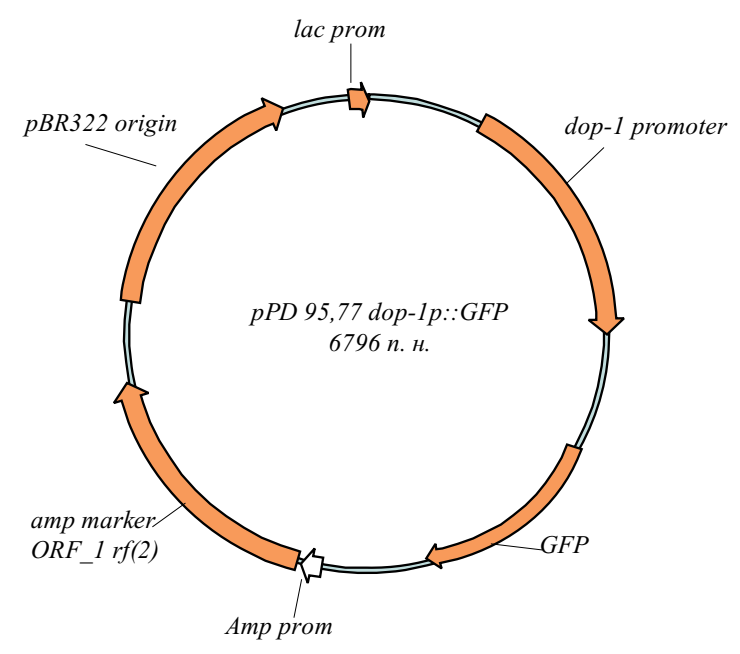

Fig. 1. Plasmid $p P D 95.77 d o p-1 p:: G F P$

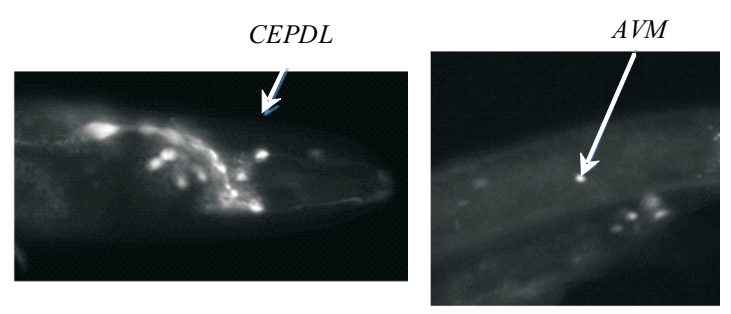

Fig. 2. dop-1::GFP expression in neurons $C$. elegans ( $a$ - tail section; $\sigma$ - head section; $b$ - midsection). VNC-ventricle nerve trunk

performed using PDS-1000/He system (Biorad, USA) with the pressure of $9.3 \mathrm{MPa}$ and $711 \mathrm{~mm} \mathrm{Hg}$ in the chamber.

The delivery of DNA was performed using gold nanoparticles, covered with linearized plasmid DNA in 3:1 ratio by a standard method [9]. Two days prior to bombardment the C. elegans culture was synchronized, and 1 hour prior to the experiment it was transferred to dishes without bacteria. After bombardment the culture was incubated for $30 \mathrm{~min}$ at room temperature and sown to dishes with NGM agar and OP50.

The screening was started 3 days after bombardment and continued for 10 days using light and confocal microscopes.

Results and Discussion. The visualization of GFR expression under the control of the promoter of $d o p-1$ gene revealed that the expression of the target protein is mainly registered in the neurons of the head and tail
(Fig.2, $a, b$ ). In the tail of the experimental animals GFR was revealed in neurons PLM, PVQR, PVQL, ALNR, ALNL, DVAR, DVC (Fig.2,a). In the head of animals the fluorescence of GFR was detected in neurons CEPDL and CEPDR as well as in a numerous group of cells, surrounding the nervous ring (Fig.2, $b$ ), belonging to the mechanosensory neurons, accountable for the response to soft touches. Besides the cranial and caudal compartments, GFP was expressed in mechanosensory neurons PVM and AVM, located in the medium part of $C$. elegans body (Fig.2, $a, c$ ).

As GFP expression is registered only in the mechanosensory neurons it can be concluded that the dopamine receptor type 1 should determine the response to mechanic stimuli. This is indicated by the previously obtained results of changes in the reactions of animals with the dop-1 gene knockout to mechanic stimuli. However, it is surprising that all the above- 
mentioned neurons are not post-synaptic regarding dopaminergic cells of $C$. elegans which may serve as another confirmation of the hypothesis on the neuroendocrine effect of dopamine in the nervous system.

Conclusions. The expression profile of the $3 \mathrm{~kb}$ promoter region of dopamin receptor type 1 of $C$. elegans nematode was characterized using the expression of reporter $g f p$ gene, which allows employing these results in future elaboration of new approaches to search for the means of treating diseases, related to impairment of the dopaminergic neurotransmission system.

\section{B. В. Стадник', А. Регош', Х. Я. Майор ${ }^{l}$, I. С. Фоменко ${ }^{2}$, T. I. Бондарчук ${ }^{2}$ О. Я. Скляров}

Ген дофамінового рецептора першого типу експресується в механосенсорних нейронах Caenorhabditis elegans

'Ойтвош Лоранд Університет

Пл. Університетська, 1-3, Будапешт, Угорщина, 1053

${ }^{2}$ Львівський національний медичний університет імені Данила Галицького

Вул. Пекарська, 69, Львів, Україна, 79010

Резюме

Результати досліджень експресї дофамінових рецепторів в $C$. elegans наразі залишаються неповними і фрагментарними. Мета роботи полягала у вивченні профілю експресії дофамінового реuептора muny 1 (dop-1) в C. elegans з використанням промотору розміром 3 тис. п. н., 3'-кінцева послідовність якого розташована перед кодоном ATG гена dop-1. Методи. Культивування штаму C. elegans, мутантного за геном иnc-119, з агаром NGM. Для перевірки паттерну експресії dор-1 ампліфіковано промотор гена методом ПЛР. Клітини тварин кобомбардували плазмідою pPD95.77dop-1::GFP та репортерною кон- струкиією з геном иnc-119. Результати. Із застосуванням GFP як репортерного білка вдалося повні- стю охарактеризувати профіль експресї дофамінового рецептора першого типу в C. elegans. Висновки. Продемонстровано, що даний білок експресується в механосенсорних нейронах, таких як PLM, PVQR, PVQL, ALNR, ALNL, DVAR i DVC.

Ключові слова: дофамінові реиептори, механосенсорні нейрони, Caenorhabditis elegans, експресія.

\section{В. В. Стадник, А. Регош, Х. Я. Майор, И. С. Фоменко, \\ Т. И. Бондарчук, А. Я. Скляров}

Ген дофаминового рецептора первого типа экспрессируется в механосенсорных нейронах Caenorhabditis elegans

Резюме

До настоящего времени результаты исследований экспрессии дофаминовых рецепторов в С. еlegans остаются неполными и фрагментарными. Цель работы состояла в изучении профиля экспресии дофаминового реиептора первого типа (dop-1) в C. elegans c использованием промотора размером 3 тыс. $n$. н., 3'-кониевая последовательность которого расположена перед кодоном ATG гена dop-1. Методи. Культивирование итамма C. elegans, мутантного по гену ипс-119, с агаром NGM. Для проверки паттерна экспрессии dор-1 амплифицировали промотор гена методом ПЛР. Клетки животных кобомбардировали плазмидой рPD95.77dop-1: :GFP и репортерной конструкиией с геном ипс-119. Результаmы. C использованием GFP в качесве репортерного белка удалось полностью охарактеризовать профиль экспрессии дофаминового рецептора первого типа в C. elegans. Выводы. Продемонстрировано, что данный белок детектируется в механосенсорных нейронах, таких как PLM, PVQR, PVQL, ALNR, ALNL, DVAR и DVC.

Ключевые слова: дофаминовые рецепторы, механосенсорные нейроны, Caenorhabditis elegans, экспрессия.

\section{REFERENCES}

1. Missale C., Nash S. R., Robinson S. W., Jaber M., Caron M. G. Dopamine receptors: from structure to function // Physiol. Rev.1998.-78, N 1.-P. 189-225.

2. Suo S., Ishiura S., Van Tol H. H. Dopamine receptors in C. elegans // Eur. J. Pharmacol.-2004.-500, N 1-3.-P. 159-166.

3. Jorgensen E. M., Mango S. E. The art and design of genetic screens: Caenorhabditis elegans // Nat. Rev. Genet.-2002.-3, N 5.P. 356-369.

4. Boyd W. A., McBride S. J., Rice J. R., Snyder D. W., Freedman J. $H$. A high-throughput method for assessing chemical toxicity using a Caenorhabditis elegans reproduction assay // Toxicol. Appl. Pharmacol.-2010.-245, N2.-P. 153-159.

5. Chase D. L., Pepper J. S., Koelle M. R. Mechanism of extrasynaptic dopamine signaling in Caenorhabditis elegans // Nat. Neurosci.-2004.-7, N 10.-P.1096-1103.

6. Sanyal S., Wintle R. F., Kindt K. S., Nuttley W. M., Arvan R., Fitzmaurice P., Bigras E., Merz D. C., Hebert T. E., van der Kooy D., Schafer W. R., Culotti J. G., Van Tol H. H. Dopamine modulates the plasticity of mechanosensory responses in Caenorhabditis elegans // EMBO J.-2004.-23, N 2.-P. 473-482.

7. Tsalik E. L., Niacaris T., Wenick A. S., Pau K., Avery L., Hobert $O$. LIM homeobox gene-dependent expression of biogenic amine receptors in restricted regions of the $C$. elegans nervous system // Dev. Biol.-2003.-263, N 1.-P. 81-102.

8. Brindley P. J., Heath S., Waters A. P., McCutchan T. F., Sher A. Characterization of a programmed alteration in an $18 \mathrm{~S}$ ribosomal gene that accompanies the experimental induction of drug resistance in Schistosoma mansoni // Proc. Natl Acad. Sci. USA.-1991.-88, N 17.-P. 7754-7758.

9. Berezikov E., Bargmann C. I., Plasterk R. H. Homologous gene targeting in Caenorhabditis elegans by biolistic transformation// Nucleic Acids Res.-2004.-32, N 4.-e. 40. 